Article

\title{
Performance and Stability Enhancement of Perovskite-Type Nanomaterials Applied for Carbon Capture Utilizing Oxyfuel Combustion
}

\author{
Qiuwan Shen ${ }^{1, *}$, Yindi Zhang ${ }^{1}$, Haoran Ding ${ }^{2}$, Lijuan Wu ${ }^{1}$, Yongqing $X u^{2}$, Baocheng Shi ${ }^{1}$, \\ Ying Zheng ${ }^{2}$ and Jinliang Yuan ${ }^{3, *}$ \\ 1 Petroleum Engineering College, Yangtze University, Wuhan 430100, China; Yindizhang@hust.edu.cn (Y.Z.); \\ Wu_lijuan17@163.com (L.W.); shibaoch@mail.xjtu.edu.cn (B.S.) \\ 2 State Key Laboratory of Coal combustion, Huazhong University of Science \&Technology, \\ Wuhan 430074, China; abel_d@hust.edu.cn (H.D.); xuyongqing@hust.edu.cn (Y.X.); \\ zhengying@hust.edu.cn (Y.Z.) \\ 3 Faculty of Maritime and Transportation, Ningbo University, Fenghua Road 818, Ningbo 315211, China \\ * Correspondence: shenqiuwan@163.com (Q.S.); yuanjinliang@nbu.edu.cn or \\ jinliang.yuan@energy.lth.se (J.Y.); Tel: +86-27-69111061 (Q.S.); +86-574-87609795 (J.Y.)
}

Academic Editor: Fernando Rubiera González

Received: 17 October 2016; Accepted: 18 January 2017; Published: 1 February 2017

\begin{abstract}
A new series of Ba-Co-O perovskite-type oxygen carriers has been successfully synthesized by the microwave-assisted sol-gel method and further applied for producing an $\mathrm{O}_{2} / \mathrm{CO}_{2}$ mixture gas. The oxygen adsorption/desorption performance of synthesized samples was studied in a fixed-bed reactor system. Effects of A/B-site substitution on the oxygen desorption performance of Ba-Co-O-based perovskites are also included. Furthermore, the effects of operating conditions including the adsorption time and temperature as well as the desorption temperature on oxygen production performance were investigated in detail. The results indicated that $\mathrm{BaCoO}_{3-\delta}$ exhibited an excellent oxygen desorption performance among the synthesized A/B-site-substituted $\mathrm{ACoO}_{3-\delta}$ and $\mathrm{BaBO}_{3-\delta}$ samples, and that the optimal adsorption time, adsorption temperature and desorption temperature for $\mathrm{BaCoO}_{3-\delta}$ were determined to be $20 \mathrm{~min}, 850^{\circ} \mathrm{C}$ and $850{ }^{\circ} \mathrm{C}$, respectively, in this study.
\end{abstract}

Keywords: $\mathrm{CO}_{2}$ capture; $\mathrm{BaCoO}_{3-\delta}$; A/B substitution; oxygen production; adsorption/desorption

\section{Introduction}

The combustion of fossil fuels contributes to the emission of $\mathrm{CO}_{2}$ into the atmosphere, which consequently causes global warming [1-3]. Oxyfuel combustion represents a promising technique which can achieve a zero $\mathrm{CO}_{2}$ emission, which has the following advantages: (1) up to $95 \% \mathrm{CO}_{2}$ concentration in the dry flue gas; (2) improved boiler efficiency; (3) reduced power consumption in the flue gas treatment because of the small amount of flue gas involved; and (4) denitrogenation equipment and process being saved [4,5]. However, the high cost of cryogenic air separation is a major economic challenge to the deployment of the oxyfuel combustion technology with carbon capture. Therefore, it is of great significance to reduce the cost of oxygen production for the oxyfuel combustion power plants in the future when $\mathrm{CO}_{2}$ capture becomes a necessity [6].

Perovskite-type metal oxides have been receiving increasing attention for a wide variety of applications, such as in components of capacitors, microwave technology, varistors, electrodes, and immobilization of nuclear wastes, as well as being used catalysts for oxidation and hydrogenation [7-10].

Recently, a new process for producing pure $\mathrm{O}_{2}$ or $\mathrm{O}_{2} / \mathrm{CO}_{2}$ gas streams by a perovskite-type oxygen carrier was proposed for oxy-fuel combustion technology [11]. The oxygen production processes based on perovskite are, as shown in Figure 1, as follows: (1) the $\mathrm{O}_{2}$ adsorption process, 
in which air is used as a feed gas to recover the perovskite structure; (2) the $\mathrm{O}_{2}$ desorption process, in which $\mathrm{CO}_{2}$ is used as a sweep gas to desorb $\mathrm{O}_{2}$ from the perovskite and to produce an $\mathrm{O}_{2} / \mathrm{CO}_{2}$ flue gas stream. The reversible adsorption/desorption processes based on the perovskite-type oxygen carrier are described below [12]:

$$
2 A B \mathrm{O}_{3-\delta}+2 \mathrm{CO}_{2} \leftrightarrow 2 A \mathrm{CO}_{3}+B_{2} \mathrm{O}_{3}+\frac{1-2 \delta}{2} \mathrm{O}_{2}
$$

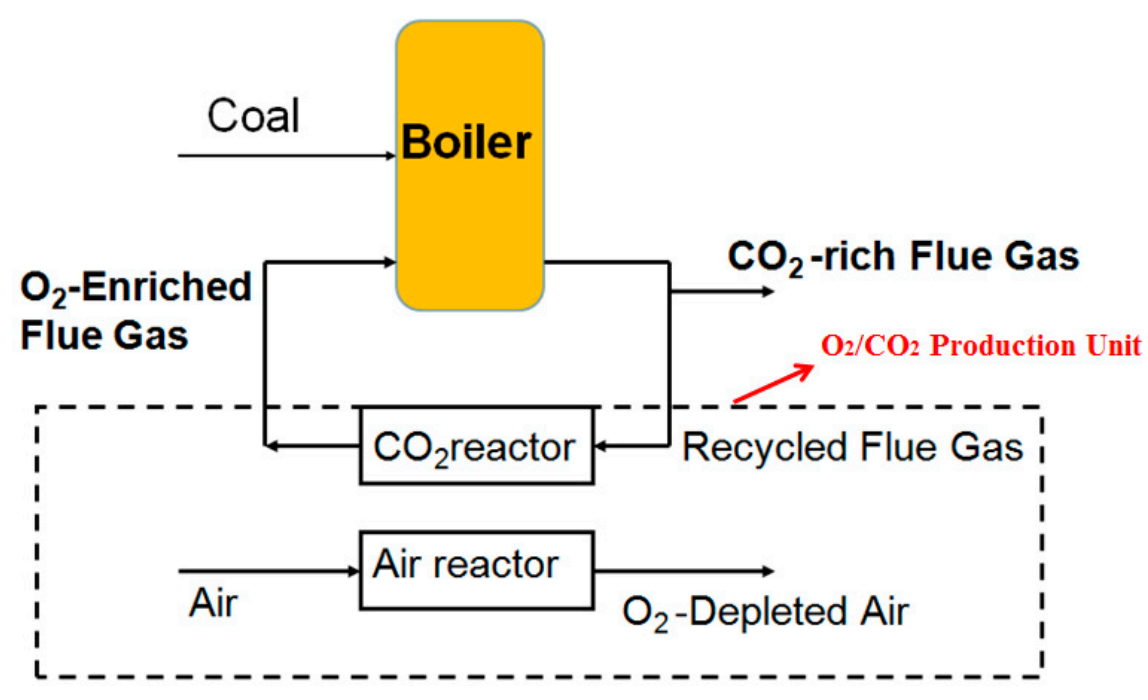

Figure 1. Simplified schematic of $\mathrm{O}_{2} / \mathrm{CO}_{2}$ production for oxyfuel combustion.

It was first reported by Teraoka et al. that $\mathrm{La}_{1-x} \mathrm{Sr}_{x} \mathrm{Co}_{1-y} \mathrm{Fe}_{y} \mathrm{O}_{3-\delta}$ has a cubic perovskite structure showing oxygen permeability at high temperatures [13]. Since then, many studies have focused on the selection and syntheses of the materials and their structural identity and stability, thermal properties, and $\mathrm{O}_{2}$ adsorption/desorption performance [14,15]. However, the relatively low oxygen desorption performance and regeneration capacity may be the major drawbacks for perovskite materials, which may lead to challenges in achieving a high efficiency of $\mathrm{O}_{2}$ production in industrial applications. Therefore, the development of perovskite-type oxygen carrier materials with excellent oxygen desorption performance and cyclic performance is necessary.

$\mathrm{Ba}-\mathrm{Co}-\mathrm{O}-\mathrm{based}$ perovskites are the promising ones that have drawn considerable public attention because of their high oxygen permeation flux when used as a dense perovskite ceramic membrane. However, only a few reports have been found evaluating the use of perovskite as an oxygen carrier for oxygen production. Therefore, the development of $\mathrm{BaCoO}_{3-\delta}$ powders needs further research. This study aims to develop $\mathrm{BaCoO}_{3-\delta}$ powders with an improved $\mathrm{O}_{2} / \mathrm{CO}_{2}$ production performance for oxyfuel combustion systems and, further, to investigate the improvement of the oxygen desorption performance of $\mathrm{BaCoO}_{3-\delta}$ through fixed-bed experiment measurements. The effects of $\mathrm{A} / \mathrm{B}$ site doping and the optimal operating conditions are also investigated and analyzed.

\section{Experiments}

\subsection{Powder Synthesis}

A series of $\mathrm{BaBO}_{3-\delta}(\mathrm{B}=\mathrm{Co}, \mathrm{Cr}, \mathrm{Cu}, \mathrm{Fe}, \mathrm{Mn}, \mathrm{Ni}, \mathrm{Zn}, \mathrm{Zr}), \mathrm{ACoO}_{3-\delta}(\mathrm{A}=\mathrm{Mg}, \mathrm{Ca}$, Sr, $\mathrm{Ba})$ and $\mathrm{Ba}_{0.5} \mathrm{Ln}_{0.5} \mathrm{CoO}_{3-\delta}(\mathrm{Ln}=\mathrm{Mg}$, Ca, Sr) were synthesized by microwave-assisted EDTA (Ethylenediaminetetraacetic acid) synthesis method [16-21]. For preparing $\mathrm{BaCoO}_{3-\delta}$ as example, the detailed microwave-assisted EDTA synthesis procedure is outlined in the flow chart shown in Figure 2. Metal nitrates $\mathrm{Ba}\left(\mathrm{NO}_{3}\right)_{2}$ and $\mathrm{Co}\left(\mathrm{NO}_{3}\right)_{2} \cdot 6 \mathrm{H}_{2} \mathrm{O}$ were used as the raw materials and all of 
analytical purities. A design amount of metal nitrates and citric acid were dissolved in the $\mathrm{NH}_{3}-\mathrm{EDTA}$ solution. The mole ratios of EDTA: citric acid: total metal ions were controlled as 1:1.5:1. $\mathrm{NH}_{4} \mathrm{OH}$ solution was employed to adjust the $\mathrm{pH}$ value of precursor solution. The solution was then gently heated and stirred at $70{ }^{\circ} \mathrm{C}$ for $5 \mathrm{~h}$ and further dried at $105^{\circ} \mathrm{C}$ for $10 \mathrm{~h}$, respectively. Finally, the gel was irradiated with microwaves at $700 \mathrm{~W}$ for $30 \mathrm{~min}$. The resultant black powders were characterized.

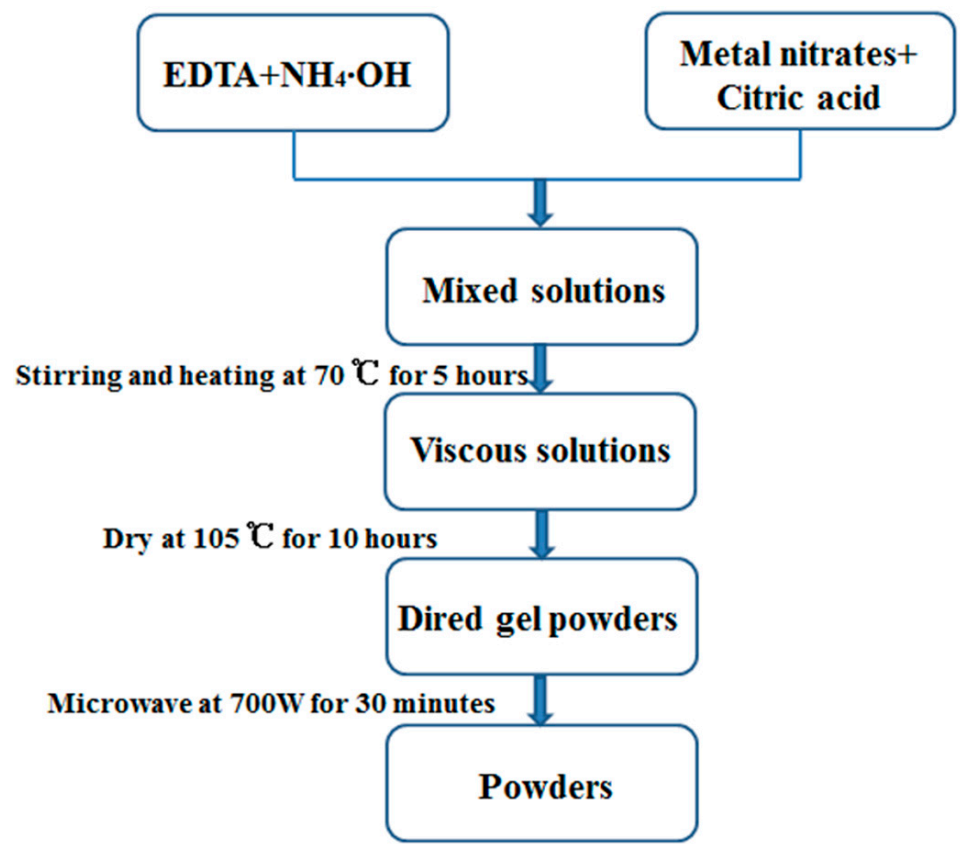

Figure 2. Flow chart of microwave-assisted EDTA synthesis.

It should be noted that the microwave source is a domestic oven (Galanz, Foshan, China), operating at $2.45 \mathrm{GHz}$ frequency with $700 \mathrm{~W}$ electricity consumption. Moreover, the dried gel powders were put in a porcelain crucible and placed inside another larger one for irradiation. In order to avoid damages, a breaker with large amount water was maintained inside during the experimental process.

\subsection{Fixed-Bed Experiments}

Oxygen adsorption/desorption experiments were performed in a fixed-bed reactor system as shown in Figure 3. It consists of a gas feeding system, a tube furnace with a quartz reactor, a gas analyzer (Gasboard 3100) and a computerized data-acquisition system. Oxygen concentrations during the desorption process were recorded to investigate the oxygen production performance of perovskite powders. About $1.0 \mathrm{~g}$ of powders was packed in the middle of the quartz reactor. Air and $\mathrm{CO}_{2} \mathrm{Were}$ respectively, used as the feed gas for adsorption step and sweep gas for desorption step.

In the adsorption step, the powders were heated to a desired adsorption temperature in a flow of air at $1 \mathrm{~atm}$ pressure with a flow rate of $200 \mathrm{~mL} / \mathrm{min}$ for $20 \mathrm{~min}$. The adsorption step was followed by the desorption step with a switch of the sweep gas from air to $\mathrm{CO}_{2}$ stream at a flow rate of $200 \mathrm{~mL} / \mathrm{min}$, and the temperature was set to the predetermined desorption temperature. The desorption step was terminated when the $\mathrm{O}_{2}$ concentration dropped nearly to zero. Then the $\mathrm{CO}_{2}$ stream was switched to air to start a new cycle of the oxygen adsorption and desorption processes. 


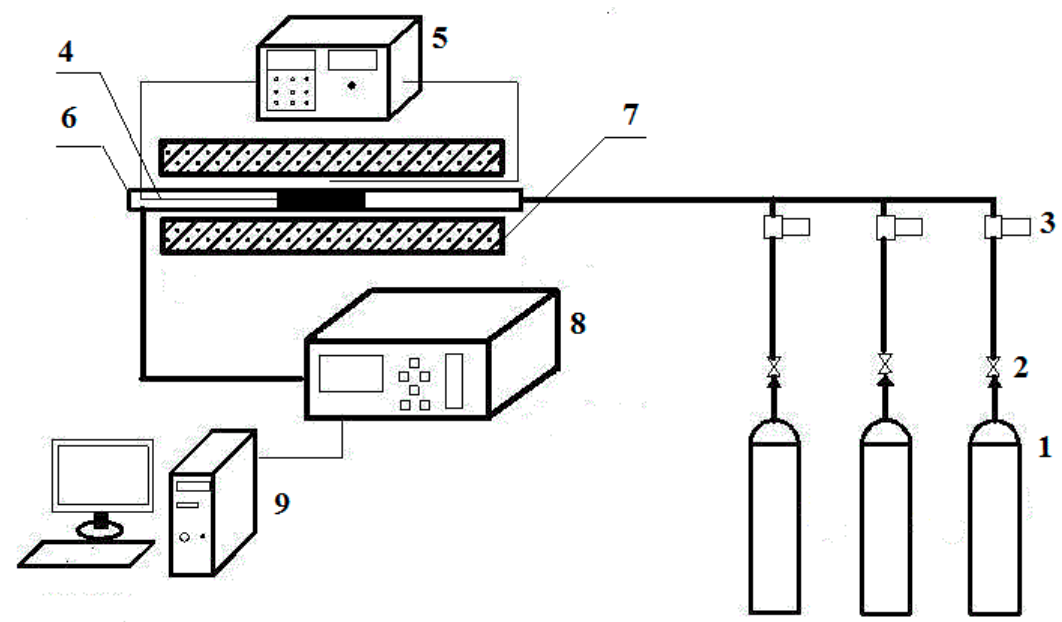

Figure 3. Schematic diagram of fixed-bed reaction system. (1) Gas cylinder; (2) valve; (3) flow controller; (4) thermocouple; (5) temperature controller; (6) quartz reactor; (7) horizontal tube furnace; (8) gas analyzer; (9) data acquisition system.

\section{Results and Discussion}

\subsection{Effects of A-Site Substitution on Oxygen Desorption Performance}

Figure 4 compares the oxygen adsorption breakthrough curves of different A-site totally/partially substituted $\mathrm{ACoO}_{3-\delta}(\mathrm{A}=\mathrm{Mg}, \mathrm{Ca}, \mathrm{Sr}, \mathrm{Ba})$ and $\mathrm{Ba}_{0.5} \mathrm{Ln}_{0.5} \mathrm{CoO}_{3-\delta}(\mathrm{Ln}=\mathrm{Mg}, \mathrm{Ca}, \mathrm{Sr}$ ) perovskite samples at the air flow rate of $200 \mathrm{~mL} / \mathrm{min}$ (the adsorption/desorption temperature is $850{ }^{\circ} \mathrm{C}$ ). As shown in Figure 4, it is clear that A-site total/partial substitution has a significant influence on the oxygen desorption properties of $\mathrm{BaCoO}_{3-\delta}$. The desorption amounts from different cases shown in Figure 4 are given in Table 1 and Figure 5, respectively, for $\mathrm{ACoO}_{3-\delta}(\mathrm{A}=\mathrm{Mg}, \mathrm{Ca}, \mathrm{Sr}, \mathrm{Ba})$ and $\mathrm{Ba}_{0.5} \mathrm{Ln}_{0.5} \mathrm{CoO}_{3-\delta}$ $(\mathrm{Ln}=\mathrm{Mg}, \mathrm{Ca}, \mathrm{Sr})$. The total oxygen desorption amount was evaluated by the integral scheme based on the obtained oxygen concentration distribution. The following equation can be used:

$$
m_{\mathrm{O}_{2}}=\frac{\Sigma C_{\mathrm{O}_{2}} \times F_{\text {out }} \times M_{\mathrm{O}_{2}}}{V_{m} \times m}
$$

where $\Sigma C_{\mathrm{O}_{2}}$ is the integration of the entire oxygen concentration during the desorption and $F_{\text {out }}(\mathrm{mL} / \mathrm{s})$ is the flow rate of the desorption effluent. It is supposed that $F_{\text {out }} \approx F_{\mathrm{CO}_{2}}$, while $M_{\mathrm{O}_{2}}(\mathrm{~g} / \mathrm{mol})$ is the molecular weight of $\mathrm{O}_{2}, m(\mathrm{~g})$ is the mass of the perovskite sample, and $m_{\mathrm{O}_{2}}(\mathrm{~g} / \mathrm{g} \cdot \mathrm{sample})$ is the oxygen desorption amount for $1 \mathrm{~g}$ of the perovskite sample.

Figure 5 shows that the oxygen desorption amount of A-site total substitution was in the following order: $\mathrm{BaCoO}_{3-\delta}>\mathrm{BaSrCoO}_{3-\delta}>\mathrm{BaCaCoO}_{3-\delta}>\mathrm{SrCoO}_{3-\delta}>\mathrm{BaMgCoO}_{3-\delta}>\mathrm{CaCoO}_{3-\delta}>\mathrm{MgCoO}_{3-\delta}$. The substitution of $\mathrm{Ba}^{2+}$ with $\mathrm{Sr}^{2+} / \mathrm{Ca}^{2+} / \mathrm{Mg}^{2+}$ reduced the oxygen desorption amount for $\mathrm{BaCoO}_{3-\delta}$. The lower desorption amount may be due to the smaller ionic radius, which is in the order $\mathrm{Ba}(1.75 \AA)$ $>\operatorname{Sr}(1.58 \AA)>\mathrm{Ca}(1.48 \AA)>\operatorname{Mg}(1.03 \AA)$. It is believed that the bigger ionic radius of Ba results in an increase of the lattice volume and in leading to a contribution to the transition of oxygen ions in the crystal. Therefore, high-temperature oxygen ( $\beta$-oxygen) desorption is usually impacted by B-site substitution, but also by A-site substitution [22]. Moreover, for a fixed B-site composition, A-site ion with the same valence but different ionic radius affects the oxygen desorption property. 


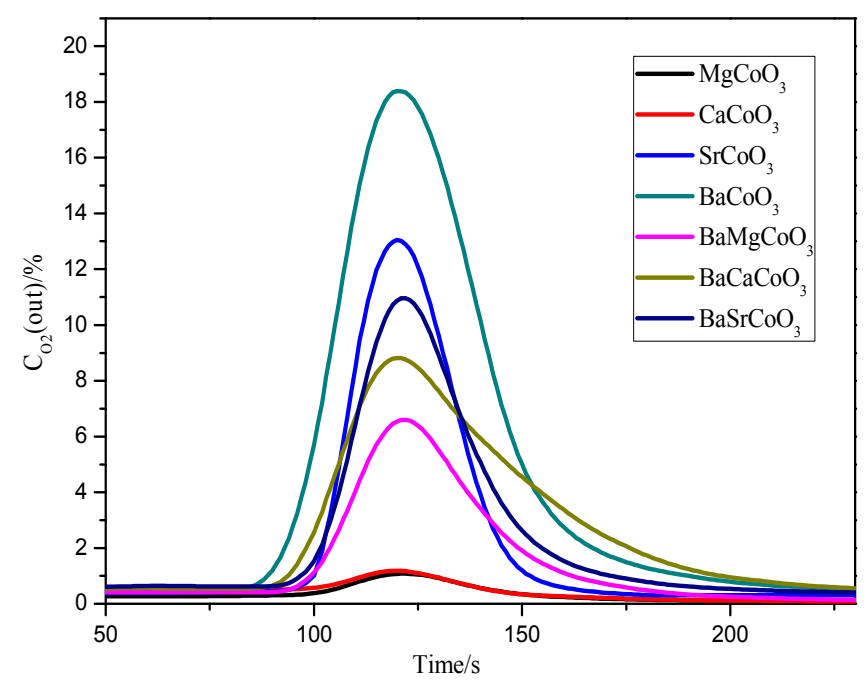

Figure 4. Oxygen desorption curves of $\mathrm{ACoO}_{3-\delta}(\mathrm{A}=\mathrm{Mg}, \mathrm{Ca}, \mathrm{Sr}, \mathrm{Ba})$ and $\mathrm{Ba}_{0.5} \mathrm{Ln}_{0.5} \mathrm{CoO}_{3-\delta}$ $(\mathrm{Ln}=\mathrm{Mg}, \mathrm{Ca}, \mathrm{Sr})$. The adsorption/desorption temperature is $850{ }^{\circ} \mathrm{C}$.

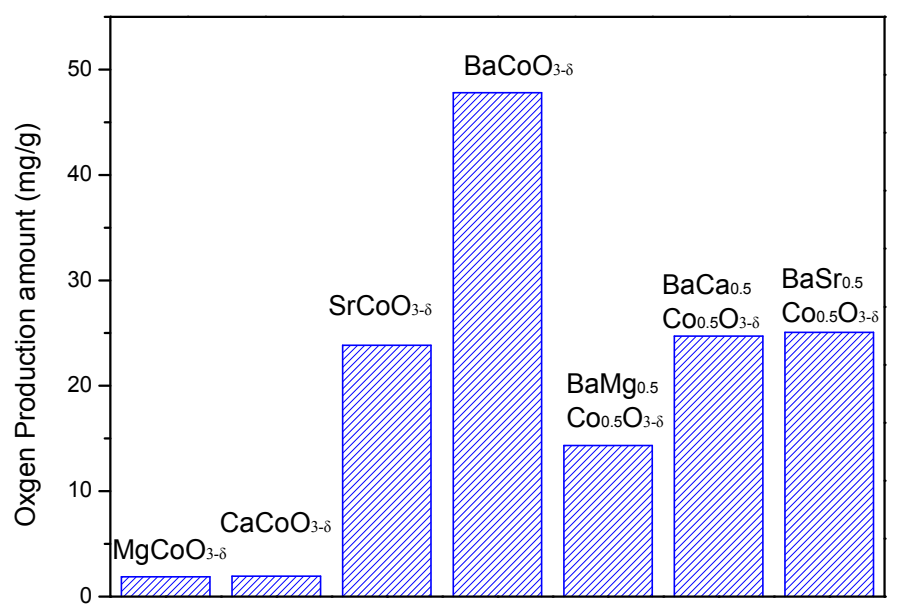

Figure 5. Comparison of oxygen desorption amount of $\mathrm{ACoO}_{3-\delta}(\mathrm{A}=\mathrm{Mg}, \mathrm{Ca}, \mathrm{Sr}, \mathrm{Ba})$ and $\mathrm{Ba}_{0.5} \mathrm{Ln}_{0.5} \mathrm{CoO}_{3-\delta}(\mathrm{Ln}=\mathrm{Mg}, \mathrm{Ca}, \mathrm{Sr})$.

\subsection{Effects of B-Site Substitution on Oxygen Desorption Performance}

The effects of B-site substitution by different transition metal ions on the oxygen production performance of $\mathrm{BaBO}_{3-\delta}$ were studied. Figure 6 shows a comparison of the oxygen desorption performance for $\mathrm{BaBO}_{3-\delta}(\mathrm{B}=\mathrm{Co}, \mathrm{Cr}, \mathrm{Cu}, \mathrm{Fe}, \mathrm{Mn}, \mathrm{Ni}, \mathrm{Zn}, \mathrm{Zr})$. It indicates that the substitution of $\mathrm{Co}$ in the $\mathrm{B}$-site with different transition metal ions had more significant effects on the oxygen desorption performance compared with A-site substitution. The B-site $\mathrm{Co}$ ion substituted by $\mathrm{Cr}, \mathrm{Cu}, \mathrm{Fe}, \mathrm{Mn}$, $\mathrm{Ni}, \mathrm{Zn}, \mathrm{Zr}$ reduced the oxygen desorption amount of $\mathrm{BaCoO}_{3-\delta}$. It indicates that $\mathrm{BaCoO}_{3-\delta}$ has the best oxygen desorption performance among the above-mentioned A/B-site-substituted $\mathrm{ACoO}_{3-\delta}$ and $\mathrm{BaBO}_{3-\delta}$. Therefore, $\mathrm{BaCoO}_{3-\delta}$ was selected as the candidate for further research. 


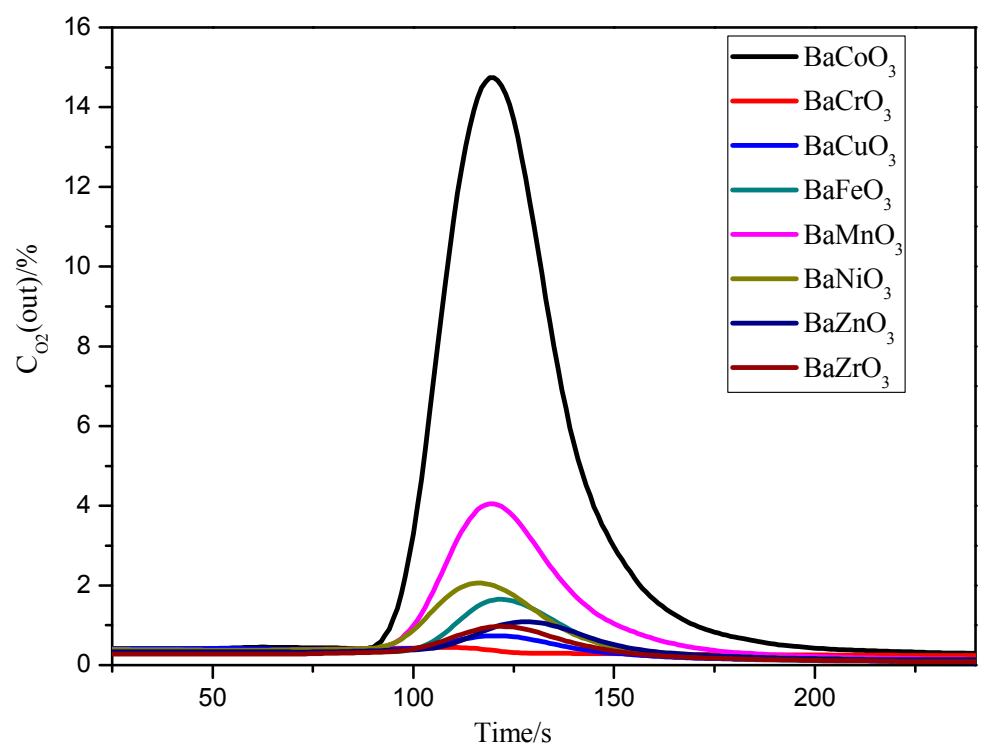

Figure 6. Oxygen desorption curves of $\mathrm{BaBO}_{3-\delta}(\mathrm{B}=\mathrm{Co}, \mathrm{Cr}, \mathrm{Cu}, \mathrm{Fe}, \mathrm{Mn}, \mathrm{Ni}, \mathrm{Zn}, \mathrm{Zr})$.

\subsection{Effects of Adsorption Time}

In order to investigate the effects of the adsorption time on the $\mathrm{BaCoO}_{3-\delta}$ oxygen production performance, $\mathrm{BaCoO}_{3-\delta}$ was exposed to an air flow for various adsorption times $(10,20,30$ or $40 \mathrm{~min}$, respectively) at $850{ }^{\circ} \mathrm{C}$ in the adsorption process. The desorption performance curves and the oxygen desorption amount for $\mathrm{BaCoO}_{3-\delta}$ with different adsorption times are shown in Figures 7 and 8, respectively. As shown in Figures 7 and 8, the oxygen production amount increased with the increase of the adsorption time, varying from $10 \mathrm{~min}$ to $30 \mathrm{~min}$. When the adsorption time increased continuously up to $40 \mathrm{~min}$, the oxygen desorption amount declined a little. Considering energy conservation and reducing the cycle time in order to improve the efficiency, it was suggested that $20 \mathrm{~min}$ of adsorption time is more efficient than a longer adsorption time. The adsorption time of $20 \mathrm{~min}$ was then chosen and further applied to study the effects of other operation conditions on the oxygen desorption performance of $\mathrm{BaCoO}_{3-\delta}$.

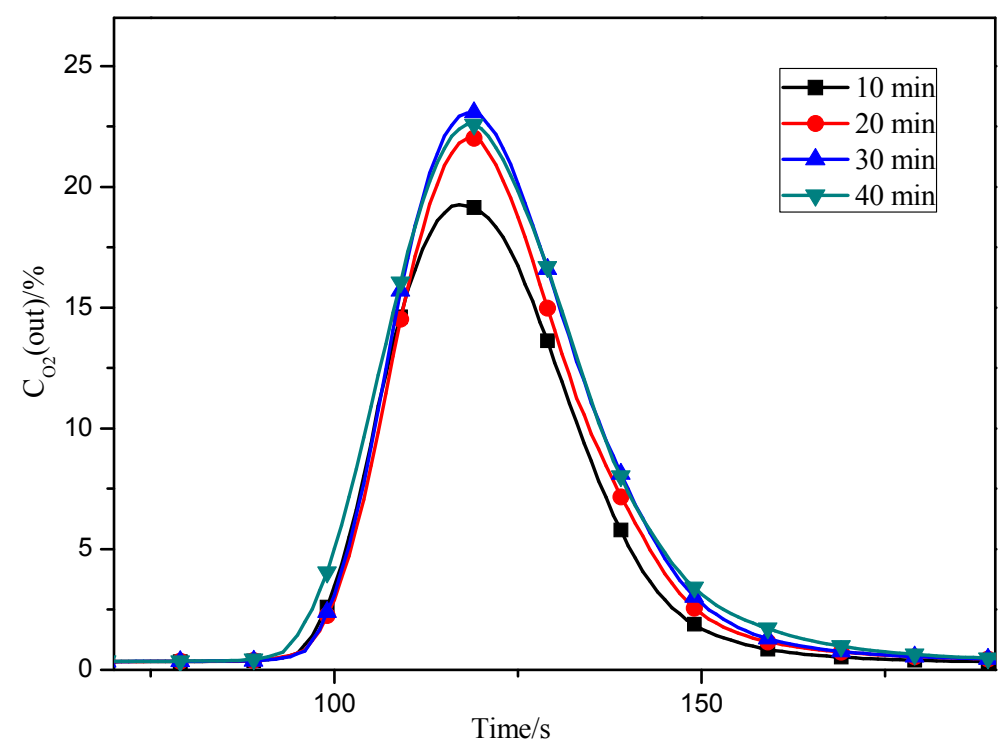

Figure 7. Oxygen desorption curves at different absorption times. 


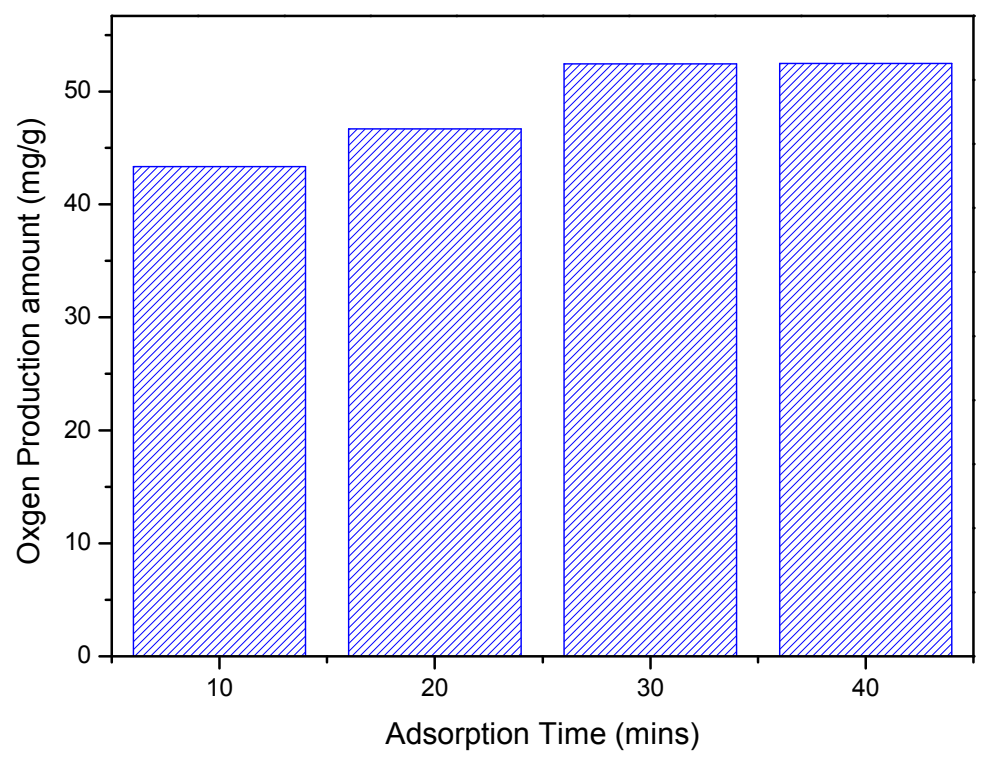

Figure 8. Comparison of oxygen desorption amount of $\mathrm{BaCoO}_{3-\delta}$ at different absorption times.

\subsection{Effects of Adsorption Temperature}

Figure 9 compares the oxygen desorption curves of $\mathrm{BaCoO}_{3-\delta}$ at different adsorption temperatures varied from $750{ }^{\circ} \mathrm{C}$ to $900{ }^{\circ} \mathrm{C}$ (with the constant desorption temperature at $850{ }^{\circ} \mathrm{C}$ ). The oxygen desorption amount calculated from the Equation (2) is given Figure 10. It shows that with the increase of the adsorption temperature, the oxygen desorption amount increased first, and then decreased. It may be because while the adsorption temperature is below $850{ }^{\circ} \mathrm{C}$, the adsorption reaction is controlled by the kinetic process. A larger amount of oxygen is adsorbed due to the faster adsorption kinetics at a higher adsorption temperature. This leads to more oxygen desorbed in the desorption step. However, when the temperature is higher than $850{ }^{\circ} \mathrm{C}$, the adsorption reaction is controlled by thermodynamics. Since the oxygen adsorption process for $\mathrm{BaCoO}_{3-\delta}$ is exothermic, the higher temperature has unfavorable effects on the adsorption process. Therefore, $850{ }^{\circ} \mathrm{C}$ was the optimal adsorption temperature for $\mathrm{BaCoO}_{3-\delta}$ in the current study.

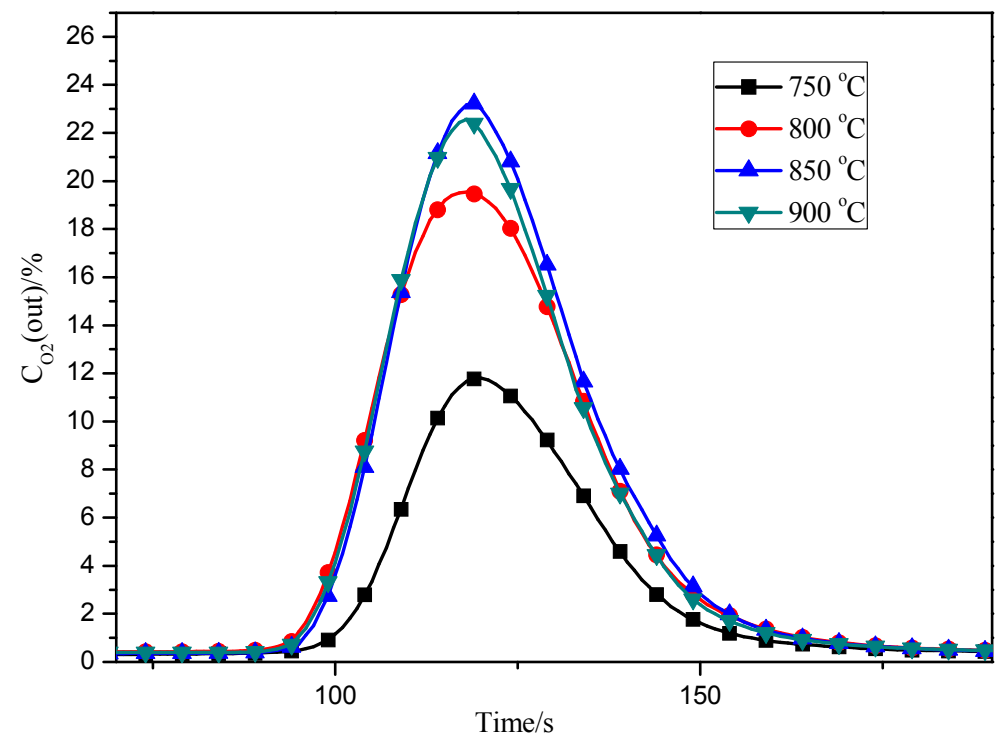

Figure 9. Oxygen desorption curves at different absorption temperatures for $\mathrm{BaCoO}_{3-\delta}$. 


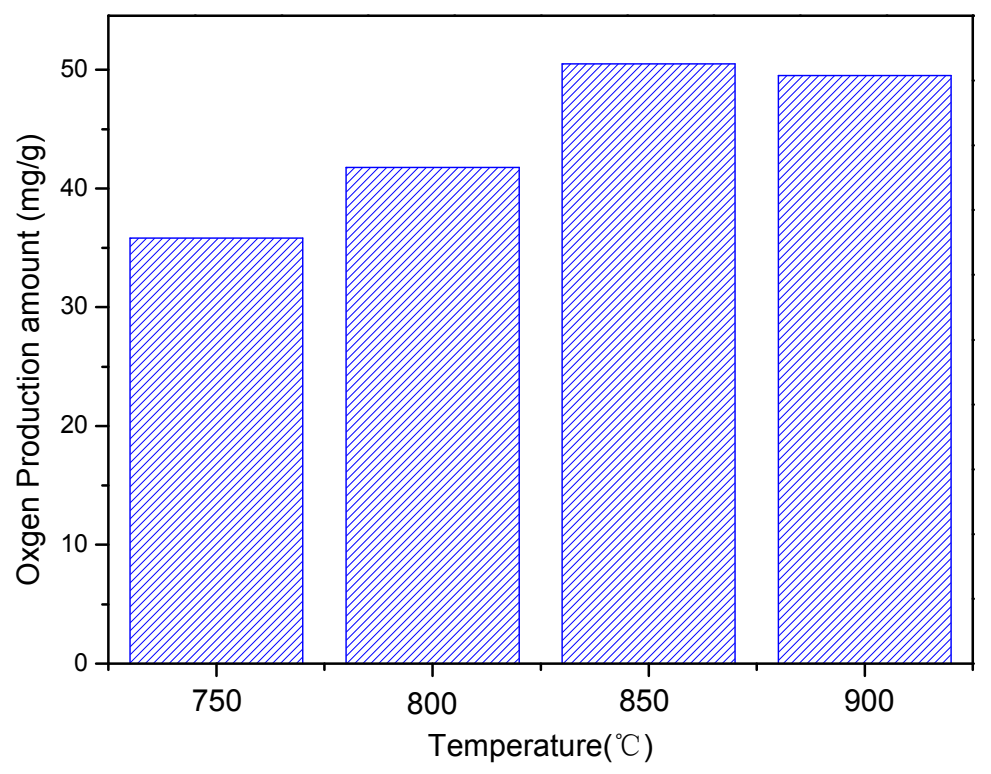

Figure 10. Comparison of oxygen desorption amount of $\mathrm{BaCoO}_{3-\delta}$ at different absorption times.

\subsection{Effects of Desorption Temperature}

Figure 11 presents the desorption performance obtained for $\mathrm{BaCoO}_{3-\delta}$ at different desorption temperatures varied from $750{ }^{\circ} \mathrm{C}$ to $900{ }^{\circ} \mathrm{C}$ (with the same adsorption temperature at $850^{\circ} \mathrm{C}$ ). As shown in Figure 12, the alteration of the oxygen desorption amount based on different desorption temperatures has the same tendency as that of the adsorption temperatures. It is clear that $850{ }^{\circ} \mathrm{C}$ was the ideal desorption temperature in this condition. It is known that the reaction between $\mathrm{CO}_{2}$ and $\mathrm{BaCoO}_{3-\delta}$ is a gas-solid reaction. The increased desorption temperature can lead to improved kinetics of the carbonation reaction. However, there is a decrease in the oxygen release quantity when the temperature reaches $900{ }^{\circ} \mathrm{C}$. It might be caused by the decrease of the sample surface area. The high reaction temperature is conducive to promoting $\mathrm{CO}_{2}$ diffusion though the product layer, making the particles aggregate with a smaller surface area, which slows down the reactions. Therefore, an optimum oxygen desorption temperature for the selected perovskites appeared in the oxygen desorption process.

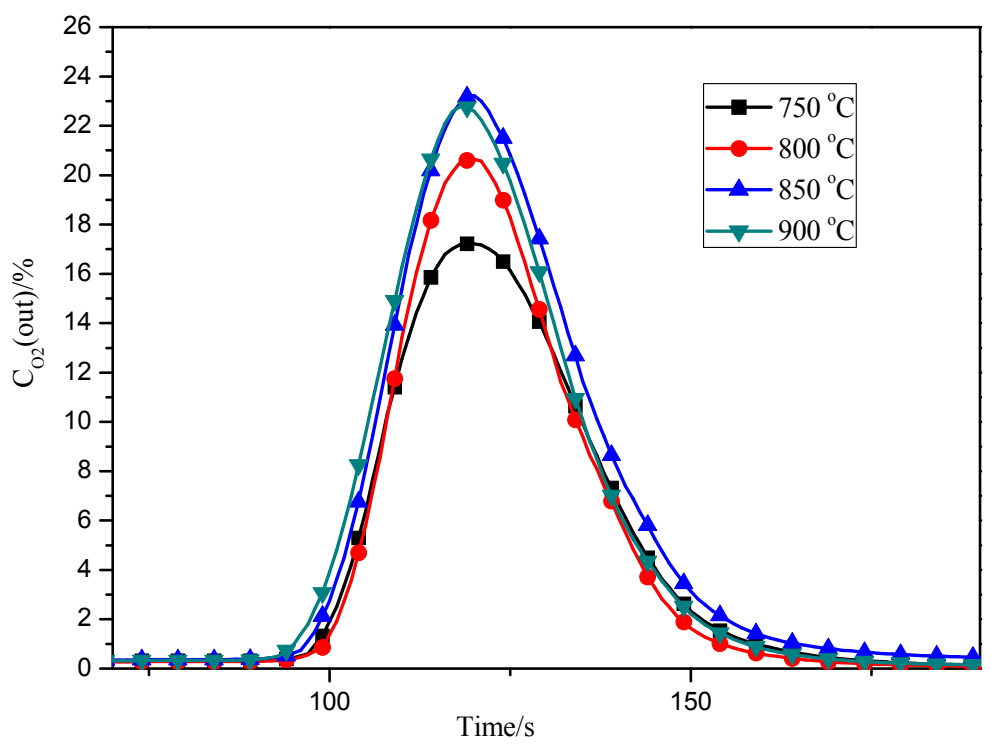

Figure 11. Oxygen desorption curves at different desorption temperatures for $\mathrm{BaCoO}_{3-\delta}$. 


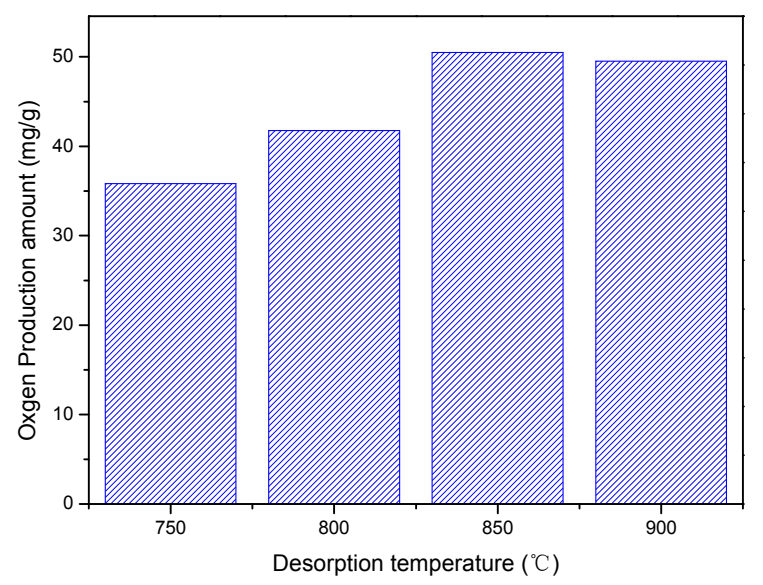

Figure 12. Comparison of oxygen desorption amount of $\mathrm{BaCoO}_{3-\delta}$ at different desorption times.

\subsection{Microstructure Analysis}

Figure 13 compares the morphologies of the fresh $\mathrm{BaCoO}_{3-\delta}$ powders, the samples after six desorption cycles and the reverted products of $\mathrm{BaCoO}_{3-\delta}$ after six test cycles. The fresh $\mathrm{BaCoO}_{3-\delta}$ powders, as seen in Figure 13A, demonstrated a homogeneous morphology and most of the particles were multifaceted, resembling hexagonal shapes. It also shows that the shapes and sizes of the fresh $\mathrm{BaCoO}_{3-\delta}$ were mostly uniform and the average particle size was about $50 \mathrm{~nm}$. When the fresh sample underwent six cycles of the desorption processes, as shown in Figure 13B, the particles became non-uniform in shape, and were composed of much bigger and irregularly shaped agglomerates, which were further merged together to form a relatively smooth surface. Figure 13C shows the reverted products of perovskite after six test cycles. As seen in Figure 13C, scattered spherical shapes could be found with a larger average particle size compared to the fresh sample.
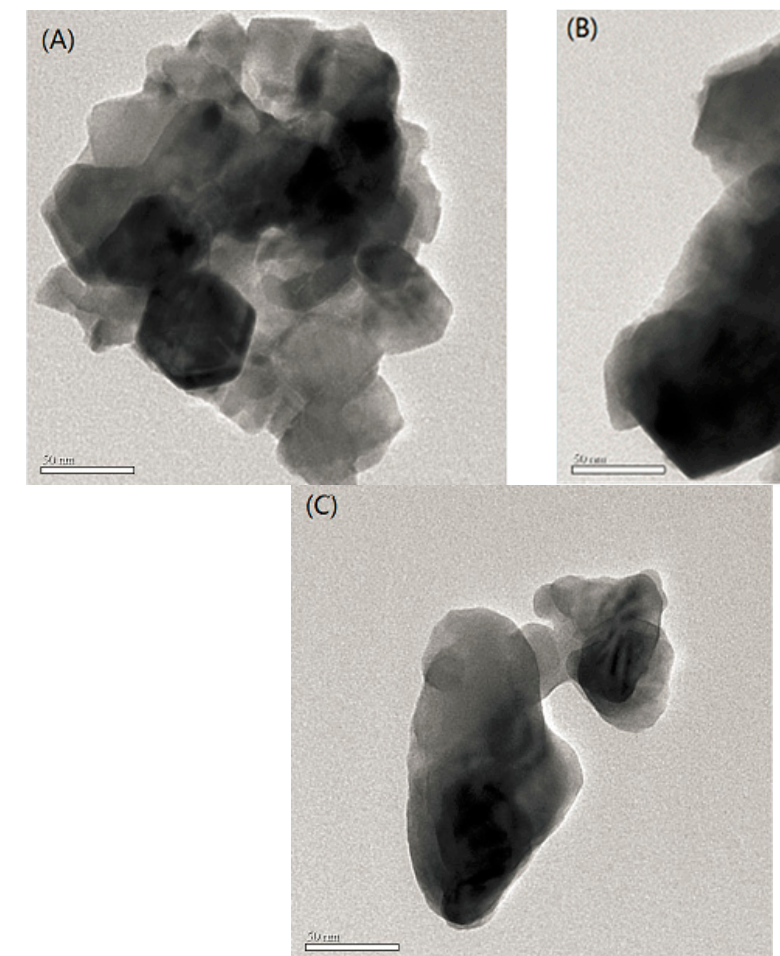

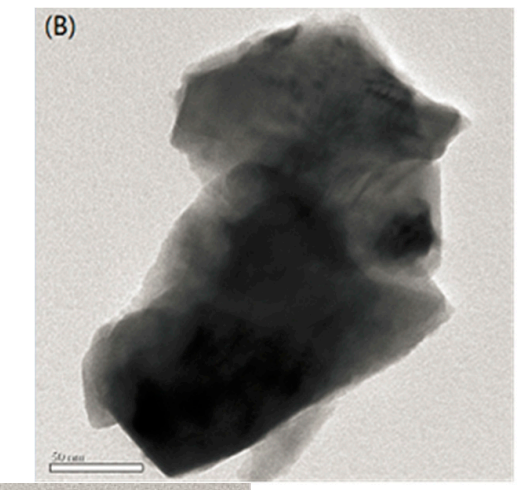

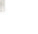 \\ (1)}




\section{Conclusions}

In this study, a new series of Ba-Co-O perovskite-type oxygen carriers were successfully synthesized by the microwave-assisted sol-gel method and applied to produce a $\mathrm{O}_{2} / \mathrm{CO}_{2}$ mixture gas. The effects of A/B-site substitutions and operating conditions on $\mathrm{BaCoO}_{3-\delta}$ perovskites were studied by fixed-bed experiments. The following conclusions can be drawn from this study:

(1) The results showed that the oxygen desorption amount of A-site substitution was in the order: $\mathrm{BaCoO}_{3-\delta}>\mathrm{BaSrCoO}_{3-\delta}>\mathrm{BaCaCoO}_{3-\delta}>\mathrm{SrCoO}_{3-\delta}>\mathrm{BaMgCoO}_{3-\delta}>\mathrm{CaCoO}_{3-\delta}>\mathrm{MgCoO}_{3-\delta}$. The substitution of $\mathrm{Ba}^{2+}$ with $\mathrm{Sr}^{2+} / \mathrm{Ca}^{2+} / \mathrm{Mg}^{2+}$ reduced the oxygen desorption amount for $\mathrm{BaCoO}_{3-\delta}$.

(2) The substitution of $\mathrm{Co}$ in the B-site with different transition metal ions had more significant effects on the oxygen desorption performance compared with A-site substitution. The B-site Co ion substituted by $\mathrm{Cr}, \mathrm{Cu}, \mathrm{Fe}, \mathrm{Mn}, \mathrm{Ni}, \mathrm{Zn}, \mathrm{Zr}$ reduced the oxygen desorption performance of $\mathrm{BaCoO}_{3-\delta}$. It is indicated that $\mathrm{BaCoO}_{3-\delta}$ had the best oxygen desorption performance among the above A/B-site-substituted $\mathrm{ACoO}_{3-\delta}$ and $\mathrm{BaBO}_{3-\delta}$.

(3) The effects of the operation parameters on the oxygen desorption performance of $\mathrm{BaCoO}_{3-\delta}$ were investigated in detail. It was found that the optimal adsorption time, adsorption temperature and desorption temperature for $\mathrm{BaCoO}_{3-\delta}$ were determined to be $20 \mathrm{~min}, 850{ }^{\circ} \mathrm{C}$ and $850{ }^{\circ} \mathrm{C}$, respectively, in this specific case.

Acknowledgments: The authors acknowledge the financial supports of the National Natural Science Foundation of China (No.51606013), the Science and Technology Innovation Team Fund of Yangtze Scholar 2015cqt01).

Author Contributions: Haoran Ding and Yongqing Xu prepare the experiments. Baocheng Shi and Lijuan Wu processed the experiments data. Jinliang Yuan, Yindi Zhang and Ying Zheng made the experimental discussion and paper modification.

Conflicts of Interest: The authors declare no conflict of interest.

\section{References}

1. Shen, Q.W.; Zheng, Y.; Luo, C.; Zheng, C.G. Development and characterization of $\mathrm{Ba}_{1-\mathrm{x}} \mathrm{Sr}_{\mathrm{x}} \mathrm{Co}_{0.8} \mathrm{Fe}_{0.2} \mathrm{O}_{3-\delta}$ perovskite for oxygen production in oxyfuel combustion system. Chem. Eng. J. 2014, 225, 462-470. [CrossRef]

2. Wang, B.W.; Xiao, G.; Song, X.Y.; Zhao, H.B.; Zheng, C.G. Chemical looping combustion of high-sulfur coal with $\mathrm{NiFe}_{2} \mathrm{O}_{4}$-combined oxygen carrier. J. Therm. Anal. Calorim. 2014, 118, 1593-1602. [CrossRef]

3. Luo, C.; Zheng, Y.; Yin, J.J.; Qin, C.L.; Ding, N.; Zheng, C.G.; Feng, B. Effect of sulfation during oxy-fuel calcination stage in calcium looping on $\mathrm{CO}_{2}$ capture performance of CaO-based sorbent. Energy Fuels 2013, 27, 1008-1014. [CrossRef]

4. Croiset, E.; Thambimuthu, K.V. $\mathrm{NO}_{x}$ and $\mathrm{SO}_{2}$ emissions from $\mathrm{O}_{2} / \mathrm{CO}_{2}$ recycle coal combustión. Fuel 2001, 80, 2117-2121. [CrossRef]

5. Buhre, B.J.P.; Elliott, L.K.; Sheng, C.D.; Gupta, R.P.; Wall, T.F. Oxy-fuel combustion technology for coal-fired power generation. Prog. Energy Combust. Sci. 2005, 31, 283-307. [CrossRef]

6. Sun, M.; Chen, X.W.; Hong, L. Leveraging the A-site $\mathrm{Ba}^{2+}-\mathrm{Sr}^{2+}$ ratio in the designated perovskite to enhance oxygen transport and structural/interfacial stability. RSC Adv. 2014, 4, 5618-5625. [CrossRef]

7. Liu, D.Y.; Gangishetty, M.K.; Kelly, T.L. Effect of $\mathrm{CH}_{3} \mathrm{NH}_{3} \mathrm{PbI}_{3}$ thickness on device efficiency in planar heterojunction perovskite solar cells. J. Mater. Chem. A 2014, 2, 19873-19881. [CrossRef]

8. Yang, M.J.; Guo, R.; Kadel, K.; Liu, Y.Y.; O'Shea, K.; Bone, R.; Wang, X.W.; He, J.; Li, W.Z. Improved charge transport of $\mathrm{Nb}$-doped $\mathrm{TiO}_{2}$ nanorods in methylammonium lead iodide bromide perovskite solar cells. J. Mater. Chem. 2014, 2, 19616-19622. [CrossRef]

9. Sun, J.C.; Li, Y.; Ji, S.J.; Wen, Z.S. The performance of cathode material of perovskite-like La-Ni-M-O for low temperature soli d oxide fuel cell. Int. J. Energy Res. 2011, 35, 1032-1036. [CrossRef]

10. Duan, L.Q.; Sun, S.Y.; Qu, W.J.; Bian, J. Study on different zero $\mathrm{CO}_{2}$ emission IGCC systems with $\mathrm{CO}_{2}$ capture by integrating OTM. Int. J. Energy Res. 2016, 40, 1410-1427. [CrossRef]

11. Yang, Z.; Lin, Y.S. High-temperature sorption process for air separation and oxygen removal. Ind. Eng. Chem. Res. 2002, 41, 2775-2784. [CrossRef] 
12. Yang, Q.; Lin, Y.S. Improved sorbent for high-temperature production of oxygen-enriched carbon dioxide stream. Ind. Eng. Chem. Res. 2007, 46, 6025-6031. [CrossRef]

13. Teraoka, Y.; Zhang, H.M.; Furukawa, S.; Yamazoe, N. Oxygen permeation through perovskite-type oxides. Chem. Lett. 1985, 11, 1743-1746. [CrossRef]

14. Rui, Z.B.; Ding, J.J.; Li, Y.D. $\mathrm{SrCo}_{0.8} \mathrm{Fe}_{0.2} \mathrm{O}_{3-\delta}$ sorbent for high-temperature production of oxygen-enriched carbon dioxide atream. Fuel 2010, 89, 1429-1434. [CrossRef]

15. Guntuka, S.; Banerjee, S.; Farooq, S.; Srinivasan, M.P. A- and B-site substituted lanthanum cobaltite perovskite as high temperature oxygen sorbent. Ind. Eng. Chem. Res. 2008, 47, 154-162. [CrossRef]

16. Shen, Q.W.; Zheng, Y.; Li, S.A.; Ding, H.R.; Xu, Y.Q.; Zheng, C.G.; Thern, M. Optimize process parameters of microwave-assisted EDTA method using orthogonal experiment for novel $\mathrm{BaCoO}_{3-\delta}$ perovskite. J. Alloys Compd. 2016, 658, 125-131. [CrossRef]

17. Zheng, J.Q.; Zhu, Y.J.; Xu, J.S.; Lu, B.Q.; Qi, C.; Chen, F.; Wu, J. Microwave-assisted rapid synthesis and photocatalytic activity of mesoporous $\mathrm{Nd}$-doped $\mathrm{SrTiO}_{3}$ nanospheres and nanoplates. Mater. Lett. 2013, 100, 62-65. [CrossRef]

18. Lin, S.L.; Fuh, M.R. Orthogonal array optimization of ultrasound-assisted emulsification-microextraction for the determination of chlorinated phenoxyacetic acids in river water. J. Chromatogr. A 2010, 1217, 3467-3472. [CrossRef] [PubMed]

19. Boldrini, S.; Mortalo, C.; Fasolin, S. Influence of Microwave-Assisted Pechini Method on $\mathrm{La}_{0.80} \mathrm{Sr}_{0.20} \mathrm{Ga}_{0.83} \mathrm{Mg}_{0.17} \mathrm{O}_{3-\delta}$ Ionic Conductivity. Fuel Cells 2012, 12, 54-60. [CrossRef]

20. Farahmand, F.; Moradkhani, D.; Safarzadeh, M.S.; Rashchi, F.; Farahmand, F.; Moradkhani, D.; Safarzadeh, M.S.; Rashchi, F. Brine leaching of lead-bearing zinc plant residues: Process optimization using orthogonal array design methodology. Hydrometallurgy 2009, 95, 316-324. [CrossRef]

21. Yang, F.; Huang, J.L.; Wuban, T.O.; Hong, Y.L.; Du, M.M.; Sun, D.H.; Jia, L.S.; Li, Q.B. Efficient Ag/CeO 2 catalysts for CO oxidation prepared with microwave-assisted biosynthesis. Chem. Eng. J. 2015, 269, 105-112. [CrossRef]

22. Zhou, W.; Shao, Z.; Ran, R.; Chen, Z. High performance electrode for electrochemical oxygen generator cell based on solid electrolyte ion transport membrane. Electrochim. Acta 2007, 52, 6297-6303. [CrossRef]

(C) 2017 by the authors; licensee MDPI, Basel, Switzerland. This article is an open access article distributed under the terms and conditions of the Creative Commons Attribution (CC BY) license (http:/ / creativecommons.org/licenses/by/4.0/). 